\title{
Peran LAZISMU Dalam Pemberdayaan Zakat Untuk Usaha, Kecil, Mikro Dan Menengah (UMKM) Di Pasar Lakessi Kota Parepare
}

\author{
Andi Kiki Patmawati \\ Prodi Manajemen Dakwah \\ IAIN Parepare
}

\section{PENDAHULUAN}

Zakat merupakan salah satu dari lima rukun islam yang wajib di lakukan oleh setiap kaum muslimin. Zakat merupakan salah satu ibadah yang bukan hanya berkaitan dengan Allah (hablumminallah), namun zakat juga mempunyai keterkaitan dengan sesama manusia (hablumminannas), sehingga dengan disyariatkan zakat diharapkan kaum muslimin lebih peduli kepada kaum muslim lain yang lebih membutuhkan dari dirinya. Zakat merupakan pranata keagamaan yang memiliki kaitan secara fungsional dengan upaya memecahkan masalah-masalah sosial, seperti kemiskinan dan kesenjangan sosial akibat perbedaan dalam kepemilikan kekayaan. Salah satu tujuan zakat adalah mempersempit jurang perbedaan ekonomi antara si kaya dan si miskin.

Agar potensi zakat sebagai sarana distribusi pendapatan dan pemerataan reski serta sebagai sarana berbuat kebajikan bagi kepentingan masyarakat belum dikelola dan didayagunakan secara maksimal. Jika diamati potensi zakat ini bila dikelola dengan baik, akan memberikan dampak yang begitu besar dalam memberdayakan ekonomi masyarakat.

Zakat adalah sebutan atas segala sesuatu yang dikeluarkan oleh seseorang sebagai kewajiban kepada Allah swt., kemudian diserahkan kepada orang-orang yang berhak menerimanya. Disebut zakat karena mengandung harapan untuk memperoleh berkah, membersihkan jiwa, dan mengembangkan harta dalam segala kebaikan. ${ }^{1}$

\footnotetext{
${ }^{1}$ Sayyid Sabiq, Fikih Sunnah jilid 2 (Jakarta: Cakrawala Publising, 2008), hal. 56
} 
Secara definisi, didalam Al-qur'an kata zakat dua puluh tujuh kali disebutkan dalam satu ayat bersama shalat ${ }^{2}$. Ini menunjukkan bahwa kewajiban zakat disetarakan dengan shalat, dan bagi orang-orang yang tidak menunaikan zakat maupun shalat maka akan mendapat ganjaran berupa balasan dari Allah di akhirat yang kekal dan abadi.

Di antara ayat-ayat yang menjelaskan tentang zakat adalah Q.S. At-Taubah ayat 103:

"Ambillah zakat dari harta mereka, guna membersihkan dan menyucikan mereka, dan berdoalah untuk mereka. Sesungguhnya doamu itu (menumbuhkan) ketenteraman jiwa bagi mereka. Allah Maha Mendengar, Maha Mengetahui".

QS. Al-Hajj ayat 41

"(Yaitu) orang-orang yang jika kami beri kedudukan di bumi, mereka melaksanakan shalat, menunaikan zakat, dan menyuruh berbuat yang makruf dan mencegah dari yang mungkar; dan kepada Allah-lah kembali segala urusan".

Menurut Undang-Undang Nomor 23 Tahun 2011 Tentang Pengelolaan Zakat Pasal 1 ayat (8) memutuskan bahwa dalam rangka mempermudah pengelolaan dana zakat, Pemerintah membolehkan masyarakat untuk membuat Lembaga Amil Zakat (LAZ) yang memiliki tugas membantu dalam pengumpulan, pendistribusian, dan pendayagunaan zakat ${ }^{3}$ Sejalan dengan itu, terdapat tiga organisasi yang diakui pemerintah dan bertugas melakukan pengelolaan zakat yang tentunya sangat memberikan kontribusi bagi kelancaran pelaksanaan zakat, yaitu Badan Amil Zakat Nasional (BAZNAS), Lembaga Amil Zakat (LAZ), dan Unit Pengelola Zakat (UPZ).

Salah satu lembaga zakat yang membantu dalam pengumpulan, pendistribusian, dan pendayagunaan zakat adalah Lembaga Amil Zakat Infaq Dan Sedekah Muhammadiyah (LAZISMU).

(Khairul and Haramain 2018; Al-Amri and Haramain 2017; Juddah 2015; Rahmawati, Wahidin, and Aris 2015; Muliati 2016; Budiman, Musyarif, and Firman 2016; Anwar 2016; Hidayat 2016; Mulianah and Hidayat 2016; Sunubi, Dalle, and Maghdalena 2016; S. A. Azis, Herdah, and Jufri 2016; Abdullah 2016; Ipandang 2017; Ilham 2017; A. Azis and Jufri 2017; Ahdar 2017; Muammar and

\footnotetext{
${ }^{2}$ Dr. Yusuf qardhawi, Hukum Zakat (Bandung: PT. Pustaka Mizan,1996), hal. 39

${ }^{3}$ Undang-Undang Republik Indonesia Nomor 23 Tahun 2011 Tentang Pengelolaan Zakat, Pasal 1 ayat (8)
} 
Suhartina 2018; Tanwir and Said 2018; Ulum and Haramain 2017; M Haramain 2016; Muhammad Haramain 2012, 2019)(Muhammad Haramain 2017; Ulum and Haramain 2017)

Lembaga Amil Zakat Infaq Dan Sedekah Muhammadiyah (LAZISMU) dalam pengelolaan zakatnya bukan hanya berkecimpung dalam pengumpulan dan pendistribusian dana zakat saja, namun juga memiliki program pendayagunaan dana zakat untuk membantu masyarakat dalam menjalankan roda perekonomiannya.

\section{PEMBAHASAN}

Toni Hartono dalam penelitiannya Pengelolaan Zakat Untuk Pemberdayaan Masyarakat Melalui Program Petani Bangkit Di Lazismu Universitas Muhammadiyah Surakarta. Penelitian Ini membahasa tentang Distribusi Dana Zakat Untuk Pemberdayaan Masyarakat Melalui Program "Petani Bangkit" Lazismu UMS. Program "Petani Bangkit" ini dilaksanakan di salah satu desa binaan milik Lazismu UMS yang berada didaerah Desa Keplik Jenar Kabupaten Sragen. Desa ini merupakan salah satu daerah terpencil dan masyarakatnya masih belum sepenuhnya sejahtera. Melalui program ini diharapkan masyarakat dapat menjadi lebih mandiri dan tidak bergantung pada orang lain dalam pemenuhan kebutuhannya. Sehingga visi zakat yakni merubah status mustahik menjadi muzakki dan kesejahteraan masyarakat dapat terwujud. ${ }^{4}$

Budi Arsanti dalam penelitiannya Pengelolaan Zakat pada lembaga Amil Zakat Infaq Shodaqoh (LAZIZ) Muhammadiyah Kabupaten GunungKidul. Penelitian ini membahas tentang bentuk pengelolaan Zakat oleh LAZIS Muhammadiyah Gunungkidul. Dalam menggunakan analisis Swot serta upaya-upaya dalam mengpotimalkan pengololaan zakat, koordinasi dan evaluasi kemudian pelaporan serta pengawasan LAZISMU. ${ }^{5}$

Karisma Ika Nugraheni dalam penelitiannya tentang Manajemen Pengumpulan Dan Pendistribusian Dana Zakat, Infak Dan Shadaqah ( Studi Kasus Di Lembaga Amil Zakat, Infak Dan Shadaqah Muhammadiyah ( Lazismu ) D.I.Yogyakarta Tahun 2017. Penelitian ini membahas tentang Pengumpulan dan pendistribusian dana zakat, infak dan shadaqah yang dilakukan oleh Lazismu D.I. Yogyakarta sudah sesuai dengan syariat Islam yang memiliki

\footnotetext{
${ }^{4}$ Toni Hartono, Pengelolaan Zakat Untuk Pemberdayaan Masyarakat Melalui Program Petani Bangkit Di Lazismu Universitas Muhammadiyah Surakarta (Skripsi Sarjana : Jurusan Hukum Ekonomi Syari'ah Fakultas Agama Islam, Surakarta, 2017), h. 13 ( 25 Juni 2017)

${ }^{5}$ Budi Arsanti, Pengelolaan Zakat pada lembaga Amil Zakat Infaq Shodaqoh (LAZIZ) Muhammadiyah Kabupaten GunungKidul (Skripsi Sarjana : Jurusan Manajemen Dakwah Fakultas Dakwah UIN Sunan Kalijaga Jogjakarta, 2007), h.41 (21 Agustus 2007)
} 
prinsip dan terdapat panitia zakat yang mengelola dana tersebut. Pengumpulan dana zakat, infak dan shadaqah yang dilakukan oleh Lazismu D.I. Yogyakarta melalui beberapa cara diantaranya jemput donasi, transfer ke bank, dan datang langsung kekantor Lazismu. ${ }^{6}$

Penelitian tersebut berbeda dengan penelitian yang akan dilakukan oleh peneliti. Yang menjadi fokus penelitian oleh Toni Hartono adalah Pengelolaan Zakat Untuk Pemberdayaan Masyarakat Melalui Program Petani Bangkit Di Lazismu. Sedangkan Budi Arsanti dalam penelitiannya yaitu membahas tentang Zakat pada lembaga Amil Zakat Infaq Shodaqoh (LAZIZ) Muhammadiyah Kabupaten GunungKidul dan penelitian Karisma Ika Nugraheni membahas tentang Manajemen Pengumpulan Dan Pendistribusian Dana Zakat, Infak Dan Shadaqah ( Studi Kasus Di Lembaga Amil Zakat, Infak Dan Shadaqah Muhammadiyah ( Lazismu ) D.I.Yogyakarta. sedangkan penelitian yang akan dilakukan peneliti adalah Peran Lazizmu Dalam Pemberdayaan Zakat Untuk Usaha Mikro, Kecil Dan Menegah (Umkm) Dipasar Lakessi Kota Parepare. Penelitian yang akan dilakukan peneliti yaitu studi kelayakan, peran pemberdayaan dan peran Lazismu, dampak dana zakat bagi UMKM di pasar lakessi kota parepare.

\section{REFERENCES}

(1) Abdullah, B. 2016. "KONSTITUSI PENDIDIKAN ISLAM DALAM MEMBANGUN MASYARAKAT MADANI." KURIOSITAS: Media Komunikasi Sosial Keagamaan 9 (2): 79-86.

(2) Ahdar, Ahdar. 2017. "TINJAUAN KRITIS DAN MENYELURUH TERHADAP FUNDAMENTALISME DAN RADIKALISME ISLAM MASA KINI." KURIOSITAS: Media Komunikasi Sosial Dan Keagamaan 10 (1): 19-36.

(3) Al-Amri, Limyah, and Muhammad Haramain. 2017. "AKULTURASI ISLAM DALAM BUDAYA LOKAL." KURIOSITAS 10 (2): 87-100.

(4) Anwar, Anwar. 2016. "KONTRIBUSI KELUARGA TERHADAP PEMBENTUKAN KARAKTER ANAK (Studi Perspektif Modal Sosial Di Kota Parepare)." KURIOSITAS 9 (1): 57-65.

(5) Azis, Aminah, and Muhammad Jufri. 2017. "IMPLEMENTASI NILAI-NILAI AJARAN TAU LOTANG TERHADAP MASYARAKAT LOKAL WATTANG BACUKIKI KOTA PAREPARE." KURIOSITAS: Media Komunikasi Sosial Dan Keagamaan 10 (2): 23-41.

(6) Azis, Sitti Aminah, Herdah Herdah, and Muhammad Jufri. 2016. "IMPLEMENTASI MODEL PEMBELAJARAN KOOPERATIF MAHASISWA PROGRAM STUDI BAHASA ARAB STAIN PAREPARE (Studi Pengembangan Pembelajaran Mata Kuliah Serumpun)." KURIOSITAS 9 (1): 81-102.

\footnotetext{
${ }^{6}$ Karisma Ika Nugraheni Manajemen Pengumpulan Dan Pendistribusian Dana Zakat, Infak Dan Shadaqah ( Studi Kasus Di Lembaga Amil Zakat, Infak Dan Shadaqah Muhammadiyah ( Lazismu )D.I.Yogyakarta Tahun (Skripsi Sarjana: Jurusan Manajemen Dakwah Fakultas Dakwah Dan Komunikasi Universitas Islam Negeri Sunan Kalijaga) h. 48 (13 April 2018)
} 
(7) Budiman, Budiman, Musyarif Musyarif, and Firman Firman. 2016. "IDEOLOGI BULETIN DAKWAH AL-ISLAM DALAM KAJIAN WACANA KRITIS." KURIOSITAS 9 (1): 2134.

(8) Haramain, M. 2016. "Al-Wasathiyyah Wa Atsaruha Fi Al-Da'wah Al-Islamiyyah: Dirasah Lugawiyyah Manhajiyyah." Langkawi: Journal of The Association for Arabic and English 2 (1): 83-100.

(9) Haramain, Muhammad. 2012. "Pemikiran Dan Gerakan Dakwah Tuan Guru M. Zainuddin Abdul Madjid Di Lombok NTB." Makassar: Universitas Islam Negeri Alauddin Makassar.

(10) - - . 2017. "DAKWAH DALAM ARUS GLOBALISASI MEDIA: PELUANG DAN TANTANGAN." KOMUNIDA: MEDIA KOMUNIKASI DAN DAKWAH 7 (1): 60-73.

(11) - - . 2019. Prinsip-Prinsip Komunikasi Dalam Al-Qur'an. Parepare: IAIN Parepare Nusantara Press.

(12) Hidayat, Wahyu. 2016. "PERSEPSI SISWA SMA KOTA PAREPARE TENTANG STAIN PAREPARE." KURIOSITAS: Media Komunikasi Sosial Keagamaan 9 (1): 49-56.

(13) Ilham, M Ilham M. 2017. "HERMENEUTIKA AL-QUR'AN." KURIOSITAS: Media Komunikasi Sosial Dan Keagamaan 10 (2): 101-19.

(14) Ipandang, Ipandang. 2017. "FILSAFAT AKHLAK DALAM KONTEKS PEMIKIRAN ETIKA MODERN DAN MISTISISME ISLAM SERTA KEMANUSIAAN." KURIOSITAS: Media Komunikasi Sosial Dan Keagamaan 10 (1): 1-18.

(15) Juddah, Abu Bakar. 2015. "ANALITIS SINTETIK TERHADAP STRATEGI PEMBELAJARAN ANDRAGOGI BERPERSPEKTIF KEMANDIRIAN DOSEN DALAM PEMBELAJARAN." Kuriositas: Media Komunikasi Sosial Dan Keagamaan 8 (2): 41-45.

(16) Khairul, Khairul, and Muhammad Haramain. 2018. "Aplikasi Digital Risalah IImu Tajwid Dalam Meningkatkan Kemampuan Baca Al Qur'an." KURIOSITAS: Media Komunikasi Sosial Dan Keagamaan 11 (2): 145-57.

(17) Muammar, Muammar, and Suhartina Suhartina. 2018. "Media Pembelajaran Berbasis Teknologi Informasi Dalam Meningkatkan Minat Belajar Akidah Akhlak." KURIOSITAS: Media Komunikasi Sosial Dan Keagamaan 11 (2): 176-88.

(18) Mulianah, Sri, and Wahyu Hidayat. 2016. "PENGEMBANGAN TES BERBASIS KOMPUTER." KURIOSITAS: Media Komunikasi Sosial Dan Keagamaan 9 (2): 27-43.

(19) Muliati, Muliati. 2016. "PENGARUH PAHAM KEAGAMAAN TERHADAP ETOS KERJA PEDAGANG PASAR SENTRAL KABUPATEN PINRANG." KURIOSITAS: Media Komunikasi Sosial Keagamaan 9 (2): 101-15.

(20) Rahmawati, Rahmawati, Wahidin Wahidin, and Aris Aris. 2015. "MATERI FIQH IBADAH DAN IMPLEMENTASINYA BAGI MAHASISWA JURUSAN SYARIAH STAIN PAREPARE." KURIOSITAS: Media Komunikasi Sosial Keagamaan 8 (1): 71-86.

(21) Sunubi, Abdul Haris, Ambo Dalle, and Maghdalena Maghdalena. 2016. "ENGLISH TEACHER INSTRUCTION IN GIVING MATERIAL BY USING CODE SWITCHING AND CODE MIXING IN SMU NEG. 2 PAREPARE." KURIOSITAS 9 (1): 35-47.

(22) Tanwir, Tanwir, and Hamdanah Said. 2018. "Inovasi Pembelajaran Guru Pendidikan Agama Islam Berbasis Teknologi Informasi." KURIOSITAS: Media Komunikasi Sosial Dan Keagamaan 11 (2): 189-210.

(23) Ulum, Ahmad Choirun, and Muhammad Haramain. 2017. "EKSISTENSI DAKWAH DALAM MERESPON PLURALISME." KOMUNIDA: MEDIA KOMUNIKASI DAN DAKWAH 7 (2): 124-38. 